\title{
Development Studies: Enduring Debates and Possible Trajectories
}

\author{
Peter Evans ${ }^{1} \cdot$ Barbara Stallings ${ }^{1}$
}

Published online: 5 May 2016

(C) The Author(s) 2016. This article is published with open access at Springerlink.com

\begin{abstract}
How should we understand current debates in development studies? More specifically, how should we understand the way in which these debates have been seen through the eyes of scholars from a range of disciplines who have been associated with Studies in Comparative International Development (SCID)? Building on an analysis of the distribution of topics, disciplines, and regions covered by articles in SCID over the past 50 years, this essay coveys a vision of development studies as seen through the lens of SCID. The four articles that follow this one help us interrogate a series of substantive issues central to development studies and their interrelationships - democracy, inequality, and the effects of the international context. We also explore two topics not covered in the articles - the role of the state in the economy and broader aspects of the international context. We conclude by speculating on how these arenas of development studies might evolve in the future.
\end{abstract}

Keywords Development · Democracy · Illiberal democracy · Inequality · International organizations

\section{Introduction}

Offering commentary on a half century of development studies is to invite accusations of hubris. We try to protect ourselves by drawing narrower boundaries around the scope of this introductory essay. While we broach questions of where development studies as a whole has been and where it is going, the bulk of our discussion focuses on development studies as seen through the lens of SCID and a symposium celebrating SCID's 50th anniversary. We proceed through four stages from the more concrete to the more speculative.

Barbara Stallings

Barbara_Stallings@brown.edu

1 Watson Institute for International and Public Affairs, Brown University, Providence, RI, USA 
The section that follows this introduction provides a snapshot of the evolving distribution of SCID articles in terms of the disciplinary affiliation of authors, the geographic focus of the empirical data, and the substantive topics that have attracted SCID authors. This analysis reveals both distributions that are consistent with what we would have expected and others that beg for explanation. Some shifts in the relative weight of different categories seem likely to reflect the distinctive place of SCID within the landscape of development studies; others are likely to reflect the overall intellectual profile of the field. We can offer guesses as to which set of dynamics is at work but, since our data are drawn only from SCID, we have no means of validating our speculations. It is safe to assume that most trends are driven by a combination of the general evolution of development studies and the specifics of SCID's place in the field.

The shift in the geographic focus of SCID articles is probably a good example of a trend driven by a combination of general and specific dynamics. The predominance of articles with a regional focus on Latin America is probably a path dependent consequence of the Latin American interests of several SCID editors, but it also reflects the more general Latin American focus of development studies as practiced in North America. The rising interest in Asia, on the other hand, almost certainly reflects a general shift in the field of development studies. The striking shift in disciplinary representation from sociology to political science probably represents a more complicated change in the relationship between those two disciplines and the field of development studies.

The distribution of substantive topics and the changes over time are even more difficult to interpret, especially since identifying the dominant substantive focus of a given article is a somewhat arbitrary process to begin with. Nonetheless, the analysis of substantive topics provides a useful backdrop for the four articles that follow this one, setting their substantive foci in relief against the overall distribution of SCID articles. First, the emphasis on democracy in this issue is firmly validated by the fact that democracy has been a dominant substantive topic in SCID, especially over the last 30 years. Likewise, the international context has been one of the dominant topics throughout SCID's five-decade history. In contrast, inequality has only recently become the main focus of articles in SCID, and even in the most recent period it is still not a highly ranked topic. Thus, this issue both reinforces traditional SCID concerns and raises the question as to whether increased interest in inequality exists in the field of development studies as a whole.

In the third section, we turn to reflections on the other articles in this anniversary issue. These four articles originated in a symposium we held at Brown University's Watson Institute for International and Public Affairs in October 2015 to celebrate SCID's 50th anniversary. We invited prominent social scientists who had published in SCID over the years to present papers on topics that have been important during the journal's history. They included Ken Roberts and Dani Rodrik on democracy, Frances Stewart on inequality, and Sarah Babb and Nitsan Chorev on the international context of development. Each of the four papers is an original assessment of a key area of development studies. In combination, they offer a provocative vision of where the evolution of the field has been and possible future trajectories in these key areas. In our discussion of the papers, we highlight the connections among the different substantive arenas and analytical perspectives on which they focus, but we had rich material to draw on in each of the individual papers. 
The two papers on democracy are quite different, but complementary. Ken Roberts offers a broad review of where the literature on democracy in the Global South has been and where it might be going. While he is very cognizant of the ways in which democratic institutions have failed to fulfill the promise that might have been attributed to them in SCID's early years, his assessment of both the returns from democratization and the possibility of expanding them is far from negative. Dani Rodrik is known as a powerful advocate for the value of democratic institutions (see, for example, his SCID article in 2000), but in his paper here he is apprehensive, arguing that the institutional forms of democracy are more and more likely to be filled with illiberal content, which robs it of its value for many citizens. Together, the two articles encapsulate major elements of ongoing debates on the future of democracy.

The third article, by Frances Stewart, focuses on inequality - an issue absolutely central to current debates on development, but oddly underrepresented in the pages of SCID, at least as the main focus of attention. Stewart offers a provocative thesis that is summed up in what she calls the "central inequality paradox," that is, "[t]he contradiction between what is, and is accepted to be, desirable, and actual policy-making." While theorizing and empirical analysis of the consequences of inequality, both in economics and in other disciplines, has moved strongly to the position that less inequality would have a range of desirable effects, actual policy, especially at the global level, reinforces inequality. At the national level, the effects of policy on inequality are more varied, but by focusing on the importance of the international level, Stewart highlights the centrality of the last article by Sarah Babb and Nitsan Chorev on the shifting structure of the international order.

Like the other three authors, Babb and Chorev offer an original prism on a crucial but complex arena of development studies. They start from an ideal-typical division of international regimes as ranging from "tightly coupled" - characterized by tight interdependence among international organizations and standardization of welldefined norms - to "loosely coupled" - decentralized and lacking in a uniformly imposed policy paradigm. Using their ideal type, they construct a periodization of the international arena, which moves from loosely coupled in the immediate post World War II period to more tightly coupled in the last third of the 20th century and seems to be heading toward a loosely coupled phase again in the first part of the 21 st century. Thinking about the international arena as varying between loosely and tightly coupled turns out to be a powerful heuristic device for thinking about ways in which the international context affects development.

The principal aim of our discussion of these articles is not to recapitulate their individual theses, but to use them to illustrate the usefulness of examining the interconnections across sub-fields for identifying the contributions of development studies as a whole to policy and theory. The connections between the study of democracy and inequality are obvious. On the one hand, as Roberts points out, the ability of democracy to diminish inequality (or its inability to do so) is one of the primary measures of its efficacy (or lack thereof). Rodrik's illiberal democracy thesis has powerful implications for Stewart's horizontal inequalities. Stewart's central inequality paradox is a provocative challenge to existing understandings of the practices and organizational logic of international organizations. Babb and Chorev's periodization of the international arena provides an overarching framework for theorizing changes in both democratization and inequality. In combination, the four articles 
demonstrate that thinking about development studies as a matrix of interlinked ideas and investigation adds value to understanding more specific practical and theoretical issues within the field.

Having offered our reflections on the four articles in this issue, it is incumbent on us to acknowledge that, as broad as they are, they can hardly encompass the whole field of development studies. While portraying the whole field is clearly beyond the reach of this essay, we try to build a few bridges from the topics covered in the four articles back to some other topics that are prominent in the overall distribution of SCID articles discussed in the first part of this essay. Thus, in the fourth section we expand our scope of inquiry to focus primarily on two interrelated bridging topics: the economic role of the state and a broader definition of the global arena.

Since the efficacy of the state as an economic actor is central to the ability of democratic regimes to deliver, looking at the economic role of the state provides a bridge between our discussion of democracy and the substantial SCID literature on economic development. At the same time, state action is the most immediate target of constraints on national development agendas imposed from the international arena, so looking at the economic role of the state provides a bridge between analysis of the national and international levels. Expanding consideration of the international arena to include the structures and agendas created by private capital and the order created by geopolitical competition among nation states enriches the periodization constructed by Babb and Chorev and helps explain Stewart's central inequality paradox by adding powerful actors whose policy preferences are not necessarily either reflections of prevailing theoretical analysis or of pursuit of the commonweal.

We conclude our reflections on development studies as seen through the SCID lens by expanding the scope of our discussion yet further to include topics that seem like natural extensions of existing SCID foci, but remain lacunae, and topics suggested by recent changes in the global trajectory of development. This last section is in part an exercise in speculation on the directions that SCID might take in the future and in part a provocation to potential SCID contributors to fill in the holes in the view of development presented in SCID.

We hope that by the time the reader finishes the sequence of discussions in our article, she or he will be eager to read the four articles that follow in this issue. Even more important, we hope that having completed the four articles that follow, the reader will be convinced of two things: first, that the field of development studies is alive and well, rife with contributions relevant to both policy formation and the theoretical agendas of the various disciplines that come together to provide the intellectual foundations for the field; second, that the pages of SCID's 50 volumes to date offer a rich menu of ideas and insights for those who would like to push the field forward.

\section{SCID's Trajectory over 50 Years}

Over the last half century, SCID has published some of the best and most-cited articles relating to development in what used to be called the Third World and is now better known as the Global South. As indicated by its title, these articles have crossed disciplinary boundaries as well as geographical frontiers and have dealt with topics as varied as democratization in Latin America, state-led industrialization in East Asia, 
ethnic conflict in Africa and South Asia, and oil politics in the Middle East. Many of the most prominent and influential social scientists working on these topics have written in the pages of SCID.

SCID was founded in 1965 by Irving Louis Horowitz, a leading sociologist from Rutgers University. The journal was part of Transaction Publishers, also founded by Horowitz, which published social science books and a number of journals. Horowitz used his extensive connections to persuade many friends and colleagues to write for his new publication. While they might not have been as well known 50 years ago, today they read like a virtual Who's Who, especially of Latin America - including former presidents, ministers, and heads of universities and institutes from around the region.

Horowitz edited the journal for 15 years. In 1979, he turned it over to one of his former students, Jay Weinstein, who was then a professor of sociology at the Georgia Institute of Technology. A decade later, John D. Martz, a political scientist and Latin Americanist from Pennsylvania State, assumed the editorship; Martz died unexpectedly in 1998 after editing SCID for 10 years. Following a short hiatus, the journal moved to UC-Berkeley, where Ruth Collier (also a political scientist and Latin Americanist) was editor for five years.

Since 2005, SCID has been housed at Brown University's Watson Institute of International and Public Affairs, forming part of the Institute's Graduate Program in Development. While Barbara Stallings acts as editor, the journal is run as a collective venture by $12-15$ Brown faculty members and some colleagues from nearby institutions. Two graduate students assist them, providing initial reading and analysis of the manuscripts that are submitted and taking charge of the mechanics of the review process. Two years after SCID arrived at Brown, Horowitz sold all of the Transaction journals to the large German publisher, Springer. Springer's ownership changed the operating style from a quite informal one to a much more professional one, including the electronic submission system that most journals use today.

A number of other changes have also taken place over the last several decades, particularly since SCID's arrival at Brown. We have tried to broaden the journal in at least two ways. On the one hand, we sought to expand toward new parts of the developing world, especially Asia and Eastern Europe. On the other hand, we wanted to bring in more economists and anthropologists to complement the sociologists and political scientists who dominated SCID's pages in its early years. We discuss below the extent to which we have succeeded in these endeavors.

\section{Trends in Disciplines and Geography in SCID}

As a way of trying to get a handle on what SCID has done over the last 50 years, and to think about whether these trends represent development studies more broadly, we reviewed the abstracts of the articles (of which there were slightly more than 800 by the end of 2015) and created a database. ${ }^{1}$ Two parts of the database are fairly "hard" the geographical focus of the articles and the disciplinary background of the author(s). The other set of data - the topics of the 800 articles - is far more subjective and thus provides a rough approximation at best of the issues considered in the journal.

\footnotetext{
${ }^{1}$ Valuable help in this endeavor was provided by Ben Bradlow, a sociology graduate student at Brown. We greatly appreciate his assistance.
} 
We are interested in three questions with respect to these data. First, do they represent more general trends in development studies in the United States? Insofar as they may be representative of US trends, would there significant differences when seen from Europe or Asia? Second, what (if anything) do these trends tell us about broader changes in the disciplines and in subjects of interest to scholars of development? And, third, are we satisfied with the trends we observe, or are there experiences in the developing world that are not being adequately studied (at least in our journal)?

Information on the disciplinary affiliation of the authors is divided into five decadelong periods since SCID's founding. Figure 1 shows there have been dramatic changes with respect to disciplines. In its first decades, SCID was mainly a publishing outlet for sociologists. Nearly 60 percent of the articles were written by scholars from that discipline in 1965-74 and 40 percent in 1975-84. In the following decades, however, sociology articles continued their decline to only 15 percent today. They were replaced by a sharp increase in publications by political scientists, which grew from 20 percent of the total in 1965-74 to more than 70 percent now. Economics articles also declined by half, from 18 percent to 9 percent. Anthropology never represented more than a handful of articles, but we published a special issue by anthropologists at the end of 2015.

How can we explain these trends? Certainly economists continue to analyze topics related to development, but they are increasingly less likely to publish in interdisciplinary journals. This trend is especially true for U.S.-based economists. Anthropologists, by contrast, have always preferred their own outlets. The most dramatic shift to be accounted for, then, is the displacement of sociology by political science. Other than the respective disciplines of the editors, the two trends probably have separate explanatory factors. The decrease in sociology articles may well reflect a decline in the perceived importance of development within sociology. This could reflect

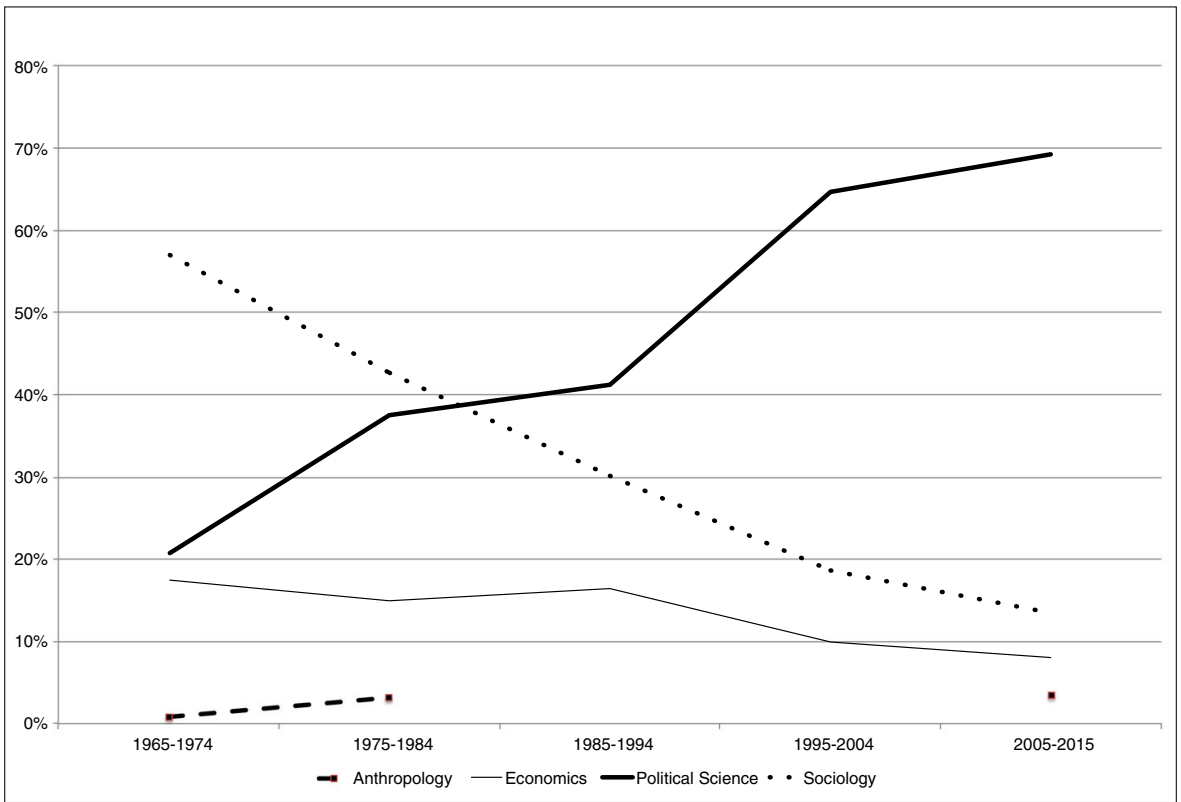

Fig. 1 Percentage share of discipline by decade, 1965-2015 
an unfortunate shift toward geographic parochialism in sociology, where the many segments of the discipline ignore the theoretical importance of doing cross-national comparative work. If conformity with contemporary methodological standards appears harder to achieve in work on development where quantitative data is more precarious and difficult to obtain, then sociology's contribution to development studies may suffer as a result. If it is in fact occurring, such a shift may be pushing sociologists, like economists, to publish more in disciplinary journals. The increased numbers of political scientists publishing on development is likely due to new topics of relevance to the discipline in developing countries, ranging from democratization to political institutions to elections and polling. At the same time, the methodological constraints imposed by disciplinary journals in political science may push political scientists interested in development toward interdisciplinary journals like SCID. In short, we might speculate that similar methodological dynamics have divergent effects in sociology and political science.

Figure 2 provides information on the geographical focus of articles in the same time frame. It indicates that Latin America initially dominated in terms of regions, providing over half of all articles between 1965 and 1974. That share is now down to slightly less than 30 percent. Articles dealing with "the world" (mainly large-N comparative articles and more general theoretical contributions) also declined. The biggest increase, not surprisingly, was in articles referring to Asia. Much smaller increases were seen in pieces on (Eastern) Europe, Africa, and the Middle East. It is interesting that these trends were generally not monotonic. For example, articles about Latin America interrupted their fall in the 1995-2004 period; articles in the "world" category increased till 1985-94, then declined. ${ }^{2}$

A separate, but related, issue has to do with the domicile of authors. Many of the pieces on Latin America in 1965-74 were written by social scientists who lived in the region. Prominent examples included George Beckford, Fernando Henrique Cardoso, Julio Cotler, Orlando Fals-Borda, Celso Furtado, Gino Germani, Pablo GonzalezCasanova, Helio Jaguaribe, Elizabeth Jelin, Rodolfo Stavenhagen, Camilo TorresRestrepo, and Francisco Weffort. Gradually, over time, a shift took place toward more US-based academics with some important contributions from Western Europe. Most recently, with the advent of the internet, we are receiving manuscripts from many parts of the world not previously well represented, especially from Asia.

Again, how can we explain these trends? The continuous dominance of Latin America - although at a lower level than before - is not surprising, given the large role the region plays with respect to the United States. Clearly, this dominance would not be found in the UK or elsewhere in Europe or in Asia. Each country or region in the industrial world has especially close contacts, mainly based on historical relationships, with certain parts of the developing world. The fact that Latin Americanists served as editors from 1988 to 2005, and founding editor Horowitz had strong connections in the region, probably also contributed, at least indirectly, to the prominence of articles on Latin America. The stronger presence of Asia is to be expected with the greater role that Asia has played in the world - and the greater developmental success that it has enjoyed. The increased number of articles on Europe since 1985 is not surprising either. While articles on Europe in SCID's first two decades were mainly on Western

\footnotetext{
$\overline{2}$ The data in Fig. 2 exclude articles involving cross-regional comparisons.
} 


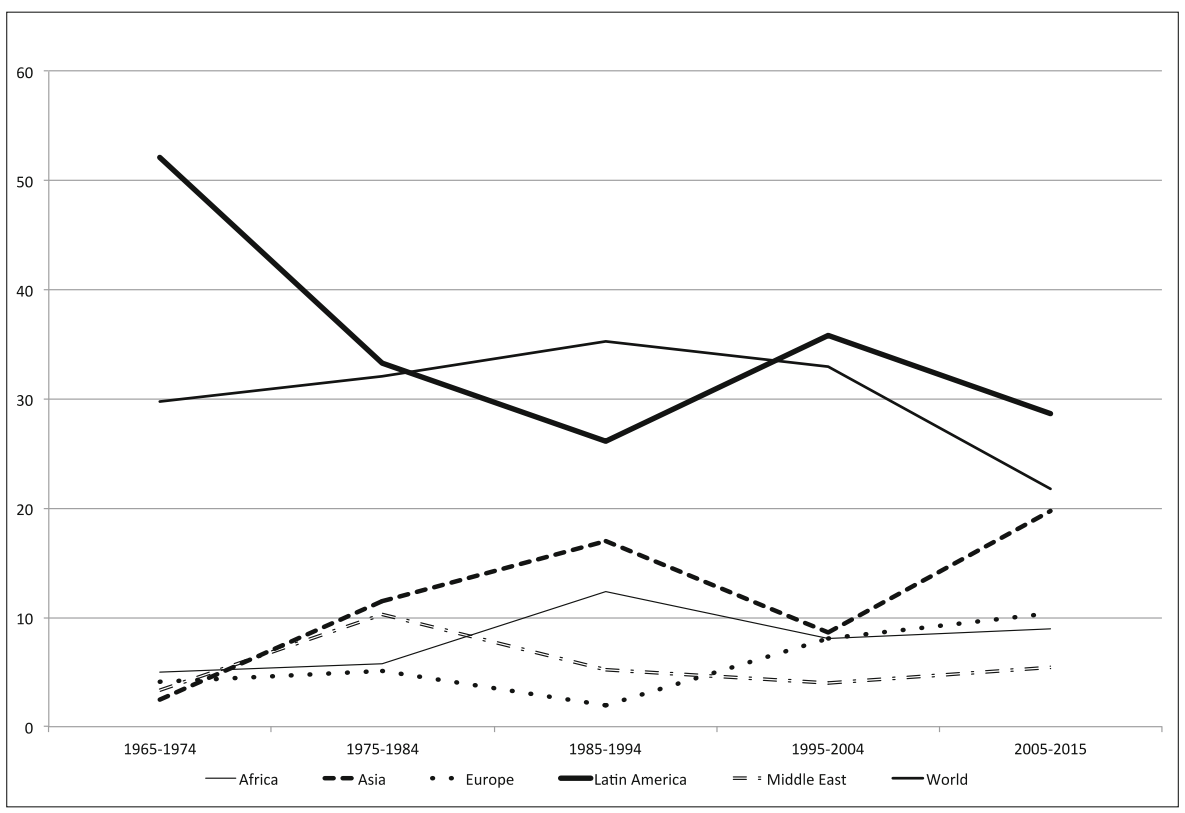

Fig. 2 Percentage share of region by decade, 1965-2015

Europe or the ex-Soviet Union, the more recent ones have mainly focused on the newly-independent nations of Central and Eastern Europe.

\section{Changes in Topics Covered in SCID}

As indicated previously, our data on topics is much softer than that on disciplines and geography. The problem, of course, is that most articles can be characterized in more than one way in terms of topic. Moreover, the way in which topics are aggregated will also have a strong influence on apparent trends. Based on our coding, four large clusters of topics have dominated the journal. They are democracy/democratization, economic development, institutions, and the international context. Their relative importance has varied. For example, democracy articles became much more prominent as authoritarian regimes fell throughout the developing world in the 1980s and 1990s. A related concern with institutions has emerged recently, while the international context was most important in the 1965-84 period and somewhat less important since then. Beyond these four, inequality (and the welfare state) has also become more important. Thus the four papers, which were presented at the 50th anniversary symposium and that appear later in this issue, are representative of articles SCID has published over time. The major topic that we do not cover is economic development. Table 1 shows the breakdown by decades of the major topics.

At a more detailed level, there are some interesting trends. In the early decades, there was more analysis of specific groups - e.g., elites, labor, peasants, and the military. Agriculture was also important. In addition to inequality and the welfare state, other new topics appearing in recent decades include the environment, gender, ethnicity, and violence. These shifts in topics are related to the disciplinary trends - and perhaps to the geographical ones too. The analysis of groups is more typical of sociological analysis 


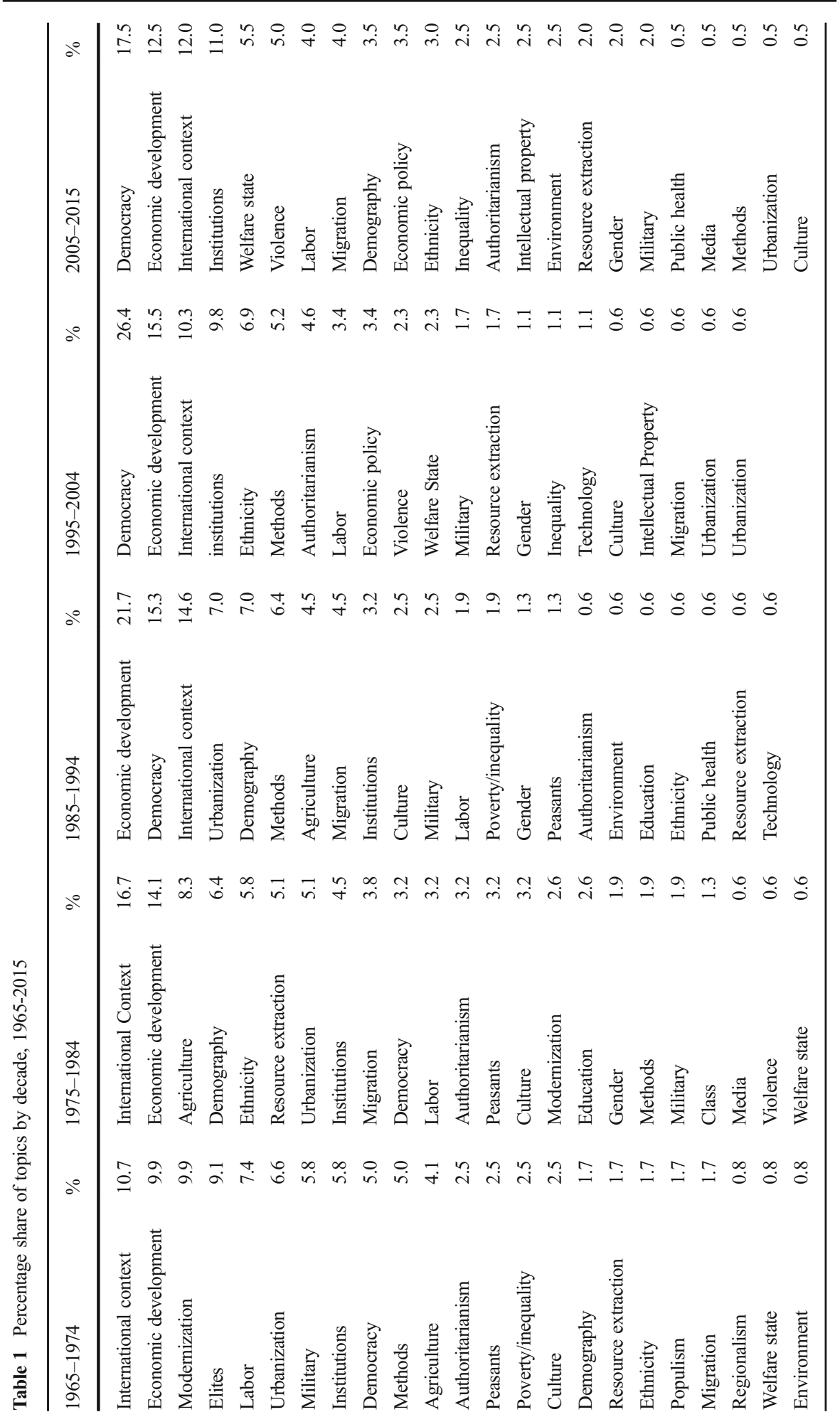


than of political science. The increased presence of topics pertaining to democracy almost certainly accompanied the rise of political science in the pages of SCID. The new topics - inequality, gender, ethnicity, and the environment - could, in principle, be of interest to both political science and sociology, but the political science version has been more prevalent in our journal. These topics of course, are of interest beyond the confines of the developing world.

\section{International context}

To get a better notion of the importance of different topics and how the profile changed over the 50 years of SCID's history, we disaggregated the four large clusters. In SCID's first two decades, 1965-84, the most prominent topic was the international context and its effect on the development process. Within that cluster, the largest number of articles focused on dependency theory. This was the approach that argued that development in Third World countries was hindered by their relationship with the international system, both economic and political. The latter was seen to extract resources from the former through various mechanisms, ranging from direct colonial rule to trade and unequal exchange to foreign direct investment to the "cooptation" of local elites who were trained in Europe or the United States. It was precisely in this period when dependency theory came onto the international agenda through the work of various authors, including Fernando Henrique Cardoso and Enzo Faletto, whose book Dependency and Development in Latin America (1979) was celebrated by a SCID symposium and special issue in 2009. This new approach was reflected in SCID's pages not only in analysis of Latin America, but also of Africa. Moreover, early versions of world systems theory were also published in SCID, including articles by Immanuel Wallerstein as well as by several of his followers.

Other ways in which the international context of development was portrayed in SCID in these two decades was through articles on foreign direct investment (FDI) and foreign aid. With respect to FDI, some of the analyses documented US investment in Latin America, but others took a broader cross regional perspective. More specific topics included practical concerns such as compensation for expropriation of foreign firms and ways in which host governments could get the maximum advantage from FDI. The role of foreign aid was also of interest to SCID authors, including several articles on the role of foundations in the aid process as well as bilateral aid agencies of the industrial countries.

From the mid-1980s to the present, the international context of development declined in relative importance in SCID's pages, although it has always remained among the leading topics. Dependency analysis continued to be represented, including a large number of articles using dependency to discuss individual countries throughout the developing world (e.g., Argentina, Brazil, and Peru, but also Botswana, Iran, and Saudi Arabia). Gradually, however, the terminology shifted from dependency toward globalization - although a discerning reader might notice that many of the same topics were being discussed under a different rubric.

With the shift toward globalization, there was a move away from individual country analysis and toward country comparisons as well as analyses of cross-border economic and other flows. Examples of topics that were examined as part of the globalization process were labor, energy, finance, information, attitudes, and standards. An 
increasingly important topic was the international division of labor and global commodity chains and their impact on individual countries or regions. Nonetheless, continuity remained with the dependency approach as exemplified by the article by Fernando Henrique Cardoso in the dependency symposium, which was entitled "New Paths: Globalization in Comparative Perspective." In addition to dependency and globalization, articles also continued to be published on FDI and foreign aid, including that by international institutions, as well as the occasional piece on foreign policy and international relations more generally.

\section{Economic development}

In SCID's third decade, economic development displaced the international context as the most-discussed topic - although it had been important all along. Over the entire period, the majority of the articles in this category were on the general operation of the economy in individual countries throughout the developing world or on specific economic sectors. Among the many examples of sectoral studies were those on industry in Argentina, Brazil, Guatemala, Spain, Taiwan, Tanzania, and South Asia; electricity in Russia; trade in Jamaica and in Japan; agriculture in Tanzania and in Ethiopia; bananas in the Caribbean; finance in Chile and in Korea; oil in Taiwan; pharmaceuticals in Africa; autos in Iran and in Latin America; and computers across the world.

In addition to country case studies, more general analyses featured discussions of economic development models. These ranged from structuralism in early postwar Latin America to the developmental state in East Asia in the 1970s and 1980s to market-led economies in many parts of the developing world in the 1990s. A recent example was a set of articles published in 2002 on Amartya Sen's capabilities approach. Closely related were articles on the economic development process in general and on economic policies, such as inflation and stabilization, privatization, trade, financial liberalization, property rights, and strategies to avoid the "middle-income trap." Needless to say, this second group of articles was much more common in the last two decades as were a number of analyses of the role of the private sector in economic development and public-private partnerships. A surprising absence was articles on economic crises although this topic was addressed under other rubrics.

The role of the state in economic development has been of persistent interest, but the valence of the state's role has shifted substantially. The movement of the field from an early approach that took for granted a state centered model of development to a more neoliberal market-driven model to a developmental state perspective is only partially reflected in the orientations of SCID authors, as we will discuss later.

\section{Democracy}

While economic development gradually became more important for SCID authors, democracy witnessed a more abrupt rise. In the 1965-84 period, democracy was not a topic of particular interest, since this type of political regime was not very common in the developing world in that era. Thus, there were more articles on the military than democracy in the first decade. Given the emphasis on Latin America in those years, most of the articles were case studies of the few Latin American democracies. Nearly 
half the articles were about Chile, where Salvador Allende's brief attempt to institute a "democratic road to socialism" stimulated enormous interest in Latin America and beyond.

Starting in the mid-1980s, but picking up steam in the early 1990s, the process of democratization (or re-democratization) took hold in many parts of the developing world. Not surprisingly, SCID authors - and particularly the growing number of political scientists - followed this trend. Most of the increasing number of articles were again case studies, but of a much wider group of countries than was found earlier. Latin America again led the list (Bolivia, Brazil, El Salvador, Grenada, Nicaragua as well as the region as a whole), but others also appeared including Africa, East Asia, Eastern Europe, and Turkey. In addition to the case studies, a number of articles dealt with more general aspects of democracy. For example, articles were published on the role of policy elites in democratization and on the role of civil society - a topic that would become more important a bit later. The first articles on the measurement of concepts related to democracy appeared in this period, as did several historical examinations of democracy.

By 1995 and continuing to the present, an extremely rich menu of articles on many aspects of democracy was published, as this became the dominant topic in SCID. In the 1995-2004 decade, nearly a third of all articles were on democracy. They were very widely based, covering Africa, East Asia, Eastern Europe, Latin America, and the Middle East. The topics became much more specific in comparison with the general discussions of transition earlier on. New aspects included elections, public opinion, political parties, democratic consolidation, democratic legitimacy, decentralization, and civil society. A new approach began to look at the economic impact of democracy, while interest in measurement issues increased.

In the past decade, while democracy continued to be the most common topic in SCID, it fell to represent only about 15 percent of all articles. The topics covered continued to become more sophisticated. More articles dealt with the impact of democracy - both on economic growth and on welfare. A focus on leadership joined the work on political parties that had been emerging. Another new interest was on the quality of democracy, which was explored through articles on civil society, accountability, and institutions. Finally, not surprisingly, given the international economic situation during the decade, a new focus was on economic crisis and democracy.

\section{Institutions}

Institutions were not a very popular topic in SCID's early decades. Only 3 to 6 percent of total articles seemed to fit this category between 1965 and 1994. Some of those articles had to do with government bureaucracies, including state-owned enterprises, while other analyzed private-sector institutions such as the Japanese factory or the kibbutzim in Israel.

In the last two decades, however, institutions have played a more prominent role in SCID, accounting for about 10 percent of the total. Moreover, the term "institutions," with its various meanings, began to appear with frequency for the first time. For some social scientists, institutions are defined as norms or rules of the game, while for others, the term refers to specific organizations. There was no consistency in the usage of the term among SCID authors. Some articles that clearly used the latter definition included 
analysis of the police force in El Salvador, party institutions in Eastern Europe, forestry monitors in India, and participatory budgeting groups in Brazil. An article on institutions in Latin America focused on several organizations, including aviation authorities, stock exchanges, and post offices. Interestingly, a fairly large number of authors wrote about different aspects of the state in China, as this country began to make more frequent appearances in the journal.

Other articles took a more systemic view of institutions. A special issue, for example, focused on Michael Mann's concept of infrastructural power, while topics like development as institutional change were also featured. Some authors in the recent decade have focused on the impact of institutions, such as institutions and the quality of governance (e.g., corruption, patronage, bribery) and the role of institutions in determining economic performance.

\section{Methods and other topics}

In addition to its main focus on the substantive analysis of problems relating to development, SCID has also published more than two-dozen articles on methodological issues that arise in studying development. The subject matter of the methodological pieces has ranged widely. A number dealt with problems of measurement (e.g., of achievement orientation, polyarchy, decentralization, and corruption), others with operationalization and conceptualization. Problems of cross-national research and international comparisons were discussed as were issues relating to field research including ethics. Research design, including the use of sub-national research units, has been addressed. Although they go somewhat further afield, several articles focused on epistemology, especially issues of causality, and on problems of the disciplines as they relate to research on development.

An important question is whether there are topics that have not received sufficient attention. Commissioning special issues provides us with a way to highlight such topics. The special issue on population and development that was published at the end of 2015 is a good example of both focusing on the role of population and bringing anthropology into our set of disciplines. But there are other examples. The first special issue after SCID moved to the Watson Institute focused on the environment, a topic that had scarcely been addressed in SCID previously. We also brought in a group of economists through a special issue on how to avoid the middle-income trap. As mentioned earlier, a multi-disciplinary group convened in 2009 to hold a conference and produce a special issue commemorating the 40th anniversary of the publication of the Cardoso and Faletto book, Dependency and Development in Latin America. This resulted in discussion of various ways in which the international context affects the development process. Other special issues have dealt with infrastructure power, labor rights, non-state social welfare provision, violence and order in cities, international migration and home-country politics, and intellectual property and access to medicine.

In summary, the five decades since SCID's founding in 1965 have witnessed some major changes in the disciplines of the authors (fewer sociologists, more political scientists) and the geographical focus of the articles (less on Latin America and more on Asia). With respect to topics, there has been both continuity and change. New topics - such as gender, violence, and the environment - have appeared. But others, including the four we discussed above - the international context, economic development, 
democracy, and institutions - have been constants over the years, although their relative importance and the precise content have certainly evolved.

\section{Democracy, Inequality, and the Influence of International Organizations: Papers from SCID's 50th Anniversary Symposium}

The four papers presented at SCID's 50th anniversary symposium provide a panorama of past work on selected key issues in development studies. Read in combination, the four articles that emerged from the presentations do an exemplary job of reviewing a broad range of the content that has been central to SCID's contributions to debates on development. Democracy, inequality, and the influence of international organizations, which are the foci of the four papers, are all core arenas of debate in the study of development. Even more important, the papers offer, especially in dialogue with one another, a provocative and original set of insights that should help stimulate SCID's future contributors to explore innovative new ways of thinking about these issues and the comparative study of development more generally.

As discussed in the previous section and shown in Table 1, democracy and democratization have been the focus of more SCID articles over the course of the last five decades than any other topic. Regular transfers of political power based on competitive elections, in which the overwhelming majority of the citizenry are enfranchised, have become the global normative standard for regime legitimacy. In his analysis of "high quality institutions" in SCID 15 years ago, Rodrik (2000) argued that democracy was a "meta institution," which enabled the construction of a range of other institutions adapted to the circumstances of individual national societies. In his contribution to this issue, Rodrik has become less sanguine about democracy as a generic institutional form and more worried about variations in the form that may subvert its value. Before focusing on Rodrik's concerns, however, we should consider Ken Roberts' panoramic analysis of the evolution of the literature on democracy.

\section{The Uncertain Promise of Democracy}

Roberts' recent contributions to SCID (2002, 2010), which focused on Latin America, were skeptical of the prospects for building robust democracies, both because of the weakening relation between economic cleavages and party mobilization (Roberts 2002) and because of the corrosive effects of economic crises driven by global neoliberalism (Roberts and Wibbels 2010). In this article, his focus is different. Following the evolution of the literature and echoing concerns similar to Rodrik's, Roberts turns from the possibility of procedural democracy emerging in the Global South, or the probability of its survival, to the quality of democratic institutions and their consequences.

Roberts summarizes his basic premise in his conclusion, "Unlike 50 years ago, when scholarly debate centered on the viability and preconditions for democracy in the developing world, the debate has shifted decisively toward the study of its quality and significance." 3 This constitutes, in his view, "a veritable intellectual sea change."

\footnotetext{
${ }^{3}$ All quotes in this section, unless otherwise indicated, are from the other four articles in this issue.
} 
The shift was stimulated most obviously by the fact that democratic institutions, defined in modest procedural terms, have spread more widely and proved more robust than seemed possible when SCID was starting up. The problem is that their capacity to deliver transformative results appears to have been either less than theorists and politicians had imaged or to have been undercut by changing structural circumstances.

Schmitter (2014: 78-79) summarized the prevailing view: "Democracy is easier to establish and sustain than previously thought, but also less consequential in its social and political effects." Contrary to earlier pessimistic predictions, Roberts reports "few cases of outright breakdowns or authoritarian reversions in third wave democracies." Nonetheless, democracy has survived at the expense of failing to foster "significant changes in power relations, property rights, policy entitlements, economic equality, and social status."

Equally disturbing is the failure of democratic regimes to consolidate their ability to defend the basic political practices that undergird popular sovereignty. Roberts concurs with Dan Slater's (2013: 730-31) analysis that "third wave" democracies have "“careened' in an unsettled manner 'between populist and oligarchic modes of politics," often engaging in "routine transgressions of basic democratic norms" and allowing democratic contestation to be dominated by "de facto autocratic authority." In short, the survival of democratic procedures, minimally defined, has carried with it a diminishing share of the benefits traditionally considered to be an integral part of democracy rule.

This somewhat gloomy take-away does not, however, do justice to Roberts' analysis of the literature. Without repudiating Schmitter, Roberts derives a more positive line of inquiry from his analysis of the evolution of the literature: "How can we construct a transition from electoral democracy to a more substantively meaningful form of democracy that produces both liberal basic rights and freedoms for all groups in the polity and supports the transformation of public institutions in the effort to make distribution of power and resources more equitable?"

Attacking this question requires looking at democratization as "an agency-centered political process...relatively autonomous of structural determination." In short, not adopting a structural determinist position, like that of the early "bureaucratic authoritarianism" O’Donnell (1973), but opting instead for a more political process version of the emergence and development of democracy. This, in turn, shifts the focus of the democracy debate from structural prerequisites to the politically contingent establishment of institutions, particularly political parties and civil society organizations that might be deployed to constrain the state and private elites.

Analysts who have attacked the "democracy problem" from this vantage point have come up with more optimistic conclusions, especially but not exclusively those working on Latin America. For example, Huber and Stephens (2012) have used extensive historical and quantitative data to ground the argument that leftist and populist mass parties in Latin America have indeed managed to produce consequential redistributive effects.

For those who focus on institutional dynamics, simple procedural democracy can have positive repercussions, even when the substantive consequences of democracy are not realized. If the erosion of the ability of classic class cleavages to provide an effective basis for political mobilization makes it harder for modern mass parties to have a transformative impact, democratic politics has created space for "decentralized, 
communitarian constituencies" to play an active role in "deliberative, consultative, and decision-making roles in the selection of infrastructure and social service projects and the allocation of public resources." 4 While decentralized participation often challenged the role of parties as intermediaries, it sometimes enabled dynamic synergies with national political agendas, facilitating, for example, "unprecedented access to national executive office for individuals from outside traditional ruling circles."

While examples of the self-reinforcing effects of democracy are drawn most often from Latin America, researchers have made similar arguments based on institutional trajectories in Africa. Lindberg (2006), for example, argues that elections and other democratic practices help to strengthen civil liberties, stabilize regime institutions, and nourish democratic values. Likewise, researchers working on democratizing regimes in Asia, like Taiwan and Korea, point to similar connections between democratization and progressive social policies (e.g., Wong 2004; McGuire 2013). Based on his review of this literature, Roberts concludes that "the practice of relying on contested elections as the singular legitimate means for accessing public office is a critical foundation for deeper and more 'consequential' forms of popular sovereignty in the future."

\section{The Rise of Illiberal Democracy}

Dani Rodrik starts from exactly the sort of preoccupations that Roberts advocates, that is, focusing on the quality and consequences of democracy rather than simply on the emergence and persistence of regimes that meet the procedural criteria necessary to be labeled democracies. His concerns, however, are more precisely focused. The centerpiece is Fareed Zakaria's proposition that the rise of "illiberal democracies" constitutes a disturbing trend in the evolution of democratic institutions. Two decades ago Zakaria (1997: 22) argued, "Democratically elected regimes... are routinely ignoring constitutional limits on their power and depriving their citizens of basic rights and freedoms." The research of Rodrik and a colleague (Mukand and Rodrik 2015) provided an empirical foundation and analytical explanation for Zakaria's apprehension, which Rodrik expands on in his paper in this issue.

Rodrik's analysis is consistent with the intellectual tradition of work on democracy, which Roberts reviews, in that it is concerned with the quality of democracy rather than the spread of procedural democracy or its ability to endure. He starts from the dramatic growth in the number of democracies since World War II (roughly quadrupling) and their recent overtaking of non-democracies among newly created political regimes (Mukand and Rodrik 2015: Fig. 1). Then, again consistent with the literature reviewed by Roberts, he turns his focus to what he sees as a growing tendency toward democracy's failure to deliver the full set of rights traditionally associated with the term.

The main difference between Rodrik and Roberts is Rodrik's greater emphasis on the determinative power of the structural circumstances underlying contemporary transitions to democracy. Roberts suggests that explanations for the trajectory of democracy that emphasize political process have become more dominant and that consequently the origins of different configurations appear to some degree contingent and the product of voluntaristic strategic interaction. In Rodrik's argument, the political

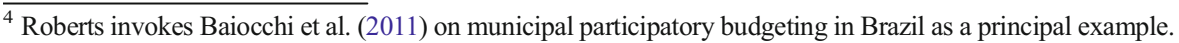


and social structural circumstances that are generic to contemporary democratization lead logically to the prevalence of illiberal rather than liberal democracy. The argument is consistent with the empirical evidence and makes analytical sense. It leads to a more pessimistic projection of the possibilities for variation in democratic regimes than the more eclectic, process-centered characterization of the literature proposed by Roberts.

The heart of Rodrik's argument lies in distinguishing political rights - essentially the right to participate in electoral competition whose outcomes are determinative of political power - from civil rights - essentially the right to be treated equally under the law with regard to freedom of speech and association, the provision of public order, human security, and the application of justice. Only when both political and civil rights are guaranteed can liberal democracy be said to exist. When political rights are preserved but civil rights systematically violated, the illiberal democracy that worries Zakaria is the result.

What makes the argument interesting is the next step, which is the postulated connection between the socio-political structures characteristic of new democracies (primarily democracies in the Global South) and a systematic impetus to abandon civil rights while maintaining political rights that makes illiberal democracy the dominant political choice in these countries. The argument is straightforward. For analytical purposes, Rodrik projects national political settlements as depending on strategic bargains that involve three groups - an elite, a non-elite majority, and minority groups. Elites may find conceding political rights advantageous, either because elections are a way of negotiating intra-elite divisions or because the costs of excluding the majority from political participation are greater than the costs of managing electoral outcomes. The majority focuses on electoral rights because elections give them the power to choose leaders and policies. ${ }^{5}$ A circumscribed extension of civil rights may affect them in a direct and serious way. The group that most depends on civil rights administered independently of electoral outcomes are non-elite minorities. Since non-elite minorities are unlikely to shape political settlements, illiberal democracy becomes a natural outcome.

Rodrik sees this tendency as reinforced by two other features of new democracies: the greater prevalence of "identity politics" and the greater difficulty of organizing nonelites around economic issues. He sees political settlements aimed at surmounting economic cleavages, which involve bread-and-butter issues, as creating less pressure to undercut civil rights than political settlements aimed at negotiating identity conflicts. Initial political settlements in new democracies are built on mobilization around nation building, which has “an implicit or explicit 'other' against which mobilized masses are aligned - a colonial adversary, a neighboring nation, or an ethnic group supposedly

\footnotetext{
5 The proposition that majorities can feel confident in their ability to exercise political rights in an institutional context where civil rights are not applied universalistically, at least in principle, is contestable. Just as the merchants and landlords who fought in England's glorious revolution saw civil rights as an essential component of their political rights, likewise it is hard to imagine that contemporary capitalist elites (and even more so non-elite majorities) might find the ability of the state to trample unimpeded on the civil rights of minorities a worrisome harbinger of their own inability to resist expropriation or the curtailment of their political rights. They may be unable to come up with strategies for constraining political elites that won't threaten their current privileges, but this is a question of inability to construct optimal political institutions rather than a structural preference for the limited application of civil rights.
} 
standing in the way of independence." This kind of mobilization is more vulnerable to settlements that exclude opponents from the legal protections of civil rights.

Economic trajectories also reinforce the tendency toward illiberal democracy. Rodrik agrees with the host of analysts who argue that the industrial working class played a key role in the construction of earlier liberal democracies. Therefore, he finds the shrinking of the relative share of manufacturing employment and the growth of service sector employment, particularly informal service sector employment, as favoring illiberal democracy. In his words, "Elites can easily divide and rule by exploiting identity cleavages and the highly heterogeneous economic interests of informal labor."

This schematic simplification of Rodrik's argument leaves out the nuance. In the full rendition of the argument, he assiduously explores possibilities for institutional creativity that might generate exceptions and countervailing possibilities that would support variations on liberal democracy. In addition, he emphasizes throughout that the argument is not mechanistically structural. The identity cleavages that are the building blocks for institutionalizing illiberal rules are "not primordial or exogenous; they can be deepened or manipulated, spurring political mobilization based on ethnicity, language, or religion." Thus, illiberal outcomes are contingent on the strategic agency of elites who "depend on the continued prevalence - and deepening - of identity cleavages to maintain their hold on power."

In the end, Rodrik's analysis of illiberal democracy overlaps with Roberts' view of the dynamics of political change. Just as Roberts emphasizes political process without rejecting the idea that structural preconditions may play a role in shaping the prospects of democracy, ${ }^{6}$ Rodrik highlights structurally shaped strategic preferences, but leaves space for the role of political process.

\section{The Central Inequality Paradox}

Rodrik's argument also connects to the distributional issues that are the center of Frances Stewart's article. Rodrik's definition of civil rights is "non-discrimination in the provision of public goods such as justice, security, education and health." These lie in the domain of what Stewart terms "horizontal inequalities" - the unequal distribution of economic resources and political power across identity groups. Education and health might as easily be considered social rights as a component of civil rights. Thus, illiberal democracy implies, not just a restricted ability to exercise rights like freedom of association, but also a failure of democracy to produce positive distributional effects. Rodrik's argument then provides a nice example of how debates on democracy connect to debates on inequality, which have been central to shifting perspectives on development.

Shifts in the conceptualization of the relationship between development and inequality since SCID's founding have been more dramatic than the changes in the conceptualization of democracy. A half century ago, an inequality-friendly theoretical climate prevailed. The Lionel Robbins view that the optimal amount of inequality was that which maximized output had triumphed over the more egalitarian Pigou version of welfare economics. In development economics, the dominant view was the Kuznets' prediction that development was likely to increase inequality in the short to medium

\footnotetext{
${ }^{6}$ See, for example, Roberts' discussion of Przeworski et al. (2000).
} 
run, even though economic transformation would eventually have the opposite effect (the inverted-U phenomenon). This combination helped provide legitimation for what Stewart characterizes as "broadly unequalising policies supported by the most powerful global institutions."

Over the course of the last 50 years, a quite different intellectual consensus has emerged. Reducing inequality, in addition to being consistent with aspirations for justice, is acknowledged to have a range of positive effects on other goals, from facilitating environmental sustainability to being "important in promoting and sustaining growth" (Berg et al. 2011: 13, as cited by Stewart). Nonetheless, "many of the policies which continue to be advocated by global institutions - and even insisted upon in conditional loans - are likely to be inequality increasing, such as reducing public expenditure, switching from direct to indirect taxation, and reducing high marginal rates of income tax." Rhetorical support for equality-increasing policies, for example in the United Nations' Sustainable Development Goals (SDGs), does not just fail to translate into diminished inequality "on the ground." It fails to translate into concrete policy. For Stewart, the result is the central inequality paradox: "[t]he contradiction between what is, and is accepted to be, desirable, and actual policy-making."

Stewart's characterization of the central inequality paradox applies primarily to the global level - to intergovernmental organizations and rich countries in their roles as donors. At the national level, it is variation in inequality that is most striking. Stewart reads the trends in national level data as suggesting that "while there are strong tendencies making for rising inequality in a globalizing capitalist world, governments can counter this by well-designed policies." As a quick rule of thumb for explaining variation, Stewart suggests that it is "a matter of the power of money balanced against the resistance generated by people's movements, and how well each organizes, in the context of increasing global pressures."

What this rule of thumb implies is that if we want to explain levels and trends in inequality at the national level, we need to use the analytical toolbox from the literature on democracy reviewed by Roberts, exploring "the changing social landscape for popular representation and participation in an era of economic liberalization." While it does not provide a sufficient condition for improved distribution, democracy may expand the space for political movements to mobilize for redistribution. If inequalityreducing policies can be connected with the emergence and robustness of particular kinds of democratic institutions, they constitute a falsification of the Schmitter (2014) proposition that democratization has "done little to bring about significant changes in power relations, property rights, policy entitlements, economic equality, and social status."

Conversely, demonstrating a positive connection between effective democratic institutions and inequality reduction adds a crucial question to Rodrik's proposition that the share of illiberal democracies is expanding. Illiberal democracies are likely to intensify horizontal inequalities rather than reduce them, but if separating civil rights from political rights also reduces the likelihood of policies that reduce vertical inequalities, then the rise of illiberal democracy becomes more menacing.

If Stewart underlines the importance of connections between the analysis of political institutions and understandings of inequality at the national level, she cautions with equal insistence against restricting analysis to the national level. While acknowledging that most analyses of the consequences of inequality are undertaken at the national 
level, including her own, Stewart argues that ultimately the global level must be given at least equal attention. Indeed, it is the global level generates the central inequality paradox. Since roughly three-fourths of total interpersonal inequality is accounted for by inter-country inequality, ${ }^{7}$ making policy efforts at the national level would be perforce inadequate to address the overall problem.

Finally Stewart argues that, "shared humanity suggests that the global level is the right one from a normative perspective." Thus, her analysis of inequality points directly toward the importance of analyzing the structure and dynamics of the international arena, which is to say to the article by Sarah Babb and Nitsan Chorev.

\section{Tightly and Loosely Coupled International Regimes}

The effects of the international context on development have been a central concern of SCID articles from its beginnings, consistently featuring as one of the top four topics in each decade as we have seen (Table 1). Babb and Chorev focus on a particular facet of the international context, the international regime as defined by international organizations such as the United Nations and the World Bank. Within this focus, they propose an analytically elegant framework for periodizing the evolution of the international regime since World War II.

Building on a dichotomous, ideal-typical division of regimes as ranging from "tightly coupled" to "loosely coupled," Babb and Chorev suggest that the regimes generated by international organizations for the first 25 years after World War II were loosely coupled. This was a period in which the constraining factors imposed by the international regime on individual nation states were "diffuse and decentralized and lacked the organizing principle of either a hegemonic idea or a coherent set of rules." The initial loosely coupled era was followed by a 30-year period during which regimes became more tightly coupled - "characterized by strong interdependence, centralized authority, and standardization." Then, starting at about the turn of the millennium, the regime generated by international organizations became again more loosely coupled, "characterized by the rise of new actors, the decentralization and fragmentation of authority, and the declining influence of policy paradigms."

One might contest either the initial conceptual categories or the periodization or both. But, if we accept both, Babb and Chorev's analysis generates a very interesting set of hypotheses for explaining the trajectory of democracy, which Roberts and Rodrik consider over the same time frame. Likewise, the Babb-Chorev framework evokes an interesting dialogue with Stewart's central inequality paradox.

Comparing Roberts' periodization of the expansion of democracy with the BabbChorev periodization suggests an intriguing interaction of international regime and democratization. Roberts characterizes the 1960s and early 1970s - which were loosely coupled in Babb and Chorev's view - as a period of receding democratization "when Latin America veered decisively toward authoritarian rule and the initial promise of decolonization gave way to the sobering reality of single-party or strong-man rule in Africa and the Middle East and to civil war in Southeast Asia." The 1990s, on the other hand - a tightly coupled period for Babb and Chorev - were for Roberts a period in which "favorable international opportunity structures were widely understood to

\footnotetext{
$\overline{{ }^{7} \text { See Lakner and Milanovic (2013). }}$
} 
encourage democratic currents in developing societies and help to compensate for the weakness of domestic structural conditions for democratic rule."

Can we give the greater coordination and convergence toward a single policy model of the tightly coupled international regime credit for helping to expand the number of democracies? Conversely, does the greater policy space created by looser coupling, make it easier for elites in the Global South to construct undemocratic regimes of their own choosing? ? $^{8}$ Most discussions of policy space and tighter coupling focus on reduced space for unorthodox economic policy - as exemplified in the dominion of the "Washington Consensus." Perhaps, however there was a similar pressure toward conformity in the political realm in the period of tighter coupling. If so, this opens up a new way of interpreting the rise of illiberal democracies.

The mapping of the number of new democracies and new non-democracies over the post World War II period by Mukand and Rodrik (2015: Fig. 1) is very consistent with Roberts' analysis. It is the period of tighter coupling at the end of the 20th century during which the number of new non-democracies takes a sharp fall, while the increase in the number of new democracies accelerates. But, this also connects the proliferation of illiberal democracies to Babb and Chorev's periodization. One way of interpreting this juxtaposition of trends is that tighter coupling increases the penalty imposed on countries that formally eschew democracy, but it does not diminish the incentives for elites to devise systems that prevent accountability and popular intrusion on their political privileges.

Viewed in this optic, illiberal democracies are not just the product of national strategies and dynamics. They also reflect a shifting international context. Tighter coupling means that the international regime (international organizations/rich countries/donors) increases the international costs imposed on countries in the Global South that abandon formal electoral institutions. If domestic political calculus makes full democracy (i.e., including universal support for civil rights) unattractive to local elites, then the combination of national and global factors favors illiberal democracy. This logic implies that the tightly coupled international regime is less willing and/or able to sanction the partial application of civil rights at the national level than it is to sanction the abandonment of formal electoral procedures. Differential capacity to enforce different sorts of international political norms would add an additional dimension to the tight vs. loosely coupled distinction.

Connecting more tightly coupled international regimes with shifts in national political outcomes would also have implications for the domestic effects of the current loosely coupled international regime. If Babb and Chorev are right that we are in a period in which looser coupling is likely to prevail, then the threat of sanctions against countries that slip out of conformity with global political norms will have less impact on national level political strategies. In countries where national political considerations make democracy strategically unattractive for local elites, we would expect these elites

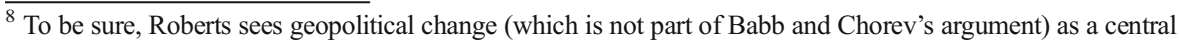
factor in this shift: "The collapse of communism in the Soviet bloc and the end of the Cold War eliminated Soviet support for authoritarian alternatives and induced the U.S. to adopt a more consistent pro-democratic stance in its spheres of influence. More favorable international opportunity structures were widely understood to encourage democratic currents in developing societies..." Nonetheless, while this is a different way of thinking about the shift from loose to tight coupling, it seems consistent with the basic logic of the BabbChorev argument.
} 
to be more likely to curtail both electoral rights and civil rights. On the other hand, the smaller number of electoral democracies that persist will do so on the basis of domestic calculations of the benefits of democracy, which may increase the proportion of electoral democracies that include full provision of civil rights.

Stewart's central inequality paradox opens up another possibility for using tight versus loose coupling in the international arena as an analytical tool. Stewart implies loose coupling of slightly different sort. The disjunction between analysis and rhetoric, on the one hand, and instantiated policy, on the other, suggests another consequence of loose coupling. The analytical and normative consensus in the international arena has become disconnected from the policies that are implemented in practice. The contradiction may be within a single organization (e.g., the World Bank) as well as between organizations. The potential realm and scope of loose coupling is thus expanded and the role of inconsistency and disjunction within the international arena becomes even more important than it is in Babb and Chorev's analysis.

The intersections between Babb and Chorev's analysis of the evolution of the international regime with Roberts' and Rodrik's analyses of democracy and development and Stewart's analysis of inequality complement the links among the first three papers that have already been considered. Overall, these intersections are a reassuring confirmation that the comparative study of development is in fact a "field." It is an intellectual arena in which findings and hypotheses in one area complement and enrich findings and hypotheses in another. Even more satisfying is the sense, made clear by the reviews of sub-fields in each paper, that the comparative study of development is a field in which later work builds on earlier work and analytical perspectives become more nuanced and satisfying over time, despite the fact that the nature of development itself has shifted dramatically over the decades.

\section{Expanding the Focus: The Role of the State and Competing Global Orders}

While the four papers in this issue do a masterful job of analyzing key fields in development studies and the connections among these fields, flagging some of the other themes and arenas that have provided the warp and woof of development studies during SCID's 50 years is still in order. Without pretending to cover the full range of themes here, we would like to explore briefly some complements to the themes set out in the papers, connecting these additional themes to those that are the focus of the papers and then pointing toward some issues that have the potential to become salient in SCID's next 25 years.

A first theme is the economic role of the state, which is a central part of the economic development topic that has characterized so many SCID articles as seen earlier. Debates on the economic capacities and agendas of states are the obvious complement to democracy debates in which the possibility of creating responsive and accountable states looms large. Without sufficient state capacity, democratic accountability is sterile. The same logic applies to equality-enhancing strategies at the national level. As Stewart points out, responses to inequality at the national level depend not just on democratic will, but on the capacity and willingness of states to pursue this agenda.

Second, we expand the discussion of the international arena to include two systems of power that have a symbiotic relation with the regimes that Babb and Chorev analyze, 
but which also compete with the regimes constructed by international organizations. The structures and agendas created by private capital is one such system; geopolitical competition among nation states is the other. The international order defined by private capital depends on and reinforces the one defined by international organizations, but the quest for profit maximization can also undermine the efforts embodied in international organizations. The logic of geopolitical competition can operate symbiotically with the regime structured by international organizations, or it can undercut it. Finally, of course, capital uses nation states to pursue its ends and vice-versa. Flagging the role of the interactions among this triumvirate of orders helps fill out an agenda for studying the international arena.

Bringing the economic role of states into the foreground and expanding the description of the international arenas complement each other as intellectual agendas. Each of these agendas also connects to the discussion of democracy and inequality at the national level. When the debate on democracy in the Global South focuses on its failure to have substantive effects on "power relations, property rights, policy entitlements, economic equality, and social status," according to Roberts (citing Schmitter 2014), it also invokes both the inability of popular politics to reshape state policies and the inadequacy of the state as an instrument of transformative change. In a globalized world, the economic role of the state and the international systems of power that it faces are inextricably linked.

Debates on the economic role of the state have evolved dramatically in the years since SCID's founding, both in the pages of SCID and beyond. At the time of SCID's founding, the centrality of the state's role in development was largely taken for granted. From the political alliances of national liberation and socialism that ranged from Nehru's post-colonial socialism to the revolutionary socialism of Mao and Ho Chi Minh to the "big push" development economics of Nurske and Rosenstein-Rodan, the centrality of the state had been a given in development studies. Then, in the 1980s and 1990s, neoliberal narratives displaced a long tradition of state-centric visions of development. During the neoliberal interlude, reforms that reduced the role of the state were in fashion. Even repressive regimes like Pinochet's Chile were redeemed ideologically by their rhetorical support for "free markets." The centrality of the state's role in development and in development studies appeared to be eclipsed by the power of market driven narratives.

The hegemony of the neoliberal narrative, especially prominent in Latin America, was challenged by events on the other side of the world. The amazing economic ascent of East Asia returned the state to prominence and introduced the concept of the developmental state. Chalmers Johnson's (1982) analysis of Japan's Ministry of International Trade and Development (MITI), which projected a state-centric vision of the organizational dynamics of industrial transformation, was the beginning. A number of analyses of Korea and Taiwan with a similar message followed (e.g., Amsden 1989; Wade 1990). Once appreciation for the state's role in Japan's industrial success was complemented by fascination with the state's involvement in the transformation of the East Asian Tigers from poor, agrarian, former colonies to emerging export manufacturing powers, the empirical foundations of the idea of the developmental state were firmly established.

In the ensuing decades, arguments for reforms that would further privilege market logics and restrict the role of the state continued to be a central preoccupation of 
development studies, but many SCID contributors offered skeptical assessments of this agenda. On the one hand, analyses of neoliberal reforms suggested deleterious effects (e.g., King 2002 on the Soviet Union). On the other hand, those who looked at specific sectors (e.g., Baer 2014 on water in Chile) failed to find a connection between private markets and positive outcomes. Moreover, those who looked at cases like Chile that were put forward as neoliberal successes (e.g., Schurman 1996; Negoita and Block 2012) suggested that, despite local rhetoric extolling private markets, a strong state role actually lay behind the economic successes that had been achieved.

Rather than touting the advantages of market-enhancing reforms, SCID contributors often focused on the consequences of institutional variation. How did countries in the Global South structure their national rules of the game, and what difference did it make for outcomes? The concept of "institutions" is useful in part because it offers a general and elastic framework into which variegated specific content can be poured. For example, North (1994: 360) defined institutions as "the rules of the game: the humanly devised constraints that structure human interaction." 9 The New Institutional Economics puts institutions at the center of the study of development. ${ }^{10}$ While many economists' applications of the frame imply that only two institutions - property rights and markets - matter, other economists, like Dani Rodrik in his 2000 SCID article, argue that the role of institutions in protecting private property is only one aspect of aggregating and legitimating societal goals.

A version of institutional analysis that gives more weight to the role of the developmental state is characteristic of many SCID contributors. In this frame, institutions provide a conceptual matrix that ties together more economically oriented work on the developmental state with the work on democracy and democratization that we focused on in the prior section. The result is a very different sort of political economy analysis than that which emerges from a perspective where figuring out how to enhance the impact of market logic is the prime goal of developmental policy (and theory).

Two consequences flow from this version of institutional analysis. First, it provides a way of integrating the political and economic dynamics of development without subordinating one to the other. Second, it forces development studies to confront the conundrum of what concrete institutional features are associated with different developmental outcomes. Rodrik's (2000) identification of democratic institutions as the "meta institutions" that produce "high quality growth" is a good example, though, as we have seen, specifying the content of democratic institutions is a challenge in itself. Portes and Smith (2008) are more specific, identifying four different structural features that are associated with better performance across a variety of institutional arenas in three Latin American countries, including features previously identified with the success of East Asian countries, like meritocratic recruitment to public bureaucracies. Other SCID authors are more skeptical of the possibility of specifying the features of effective institutions. For example, Haggard (2004: 53) challenges institutional explanations offered for East Asia's growth; sides with Rodrik in suggesting that a diversity

\footnotetext{
9 To be fair, North does not leave his definition at this most general level, going on to specify, "They are made up of formal constraints (such as rules, laws, constitutions), informal constraints (such as norms of behavior, conventions, self-imposed codes of conduct), and their enforcement characteristics."

${ }^{10}$ For example, Acemoglu et al. (2005: 386) say: "Differences in economic institutions are the fundamental cause of differences in economic development."
} 
of institutional means may accomplish the same ends; and suggests that "the search for a single institutional 'taproot' of growth is likely to be a misguided exercise...."

Debates about what concrete structural and organizational features, what specific kinds of constraining rules, and what specific sorts of cultural norms and understandings enable effective institutional performance are likely to continue for the indefinite future in the pages of SCID and in development studies more generally. Failure to resolve them should not be taken as evidence against the fruitfulness of institutional analysis, but - to the contrary - as an indicator of the richness and complexity of the arguments that it engenders.

The logic of an institutionalist perspective takes on a different character when the focus is on the interaction of national and international arenas. While traditional "realist" visions of the international arena as "Hobbesian anarchy" have, as Babb and Chorev point out, been replaced by more institutionalist projections of global regimes, no one would deny that political actors are constrained less in the international arena by shared rules of the game than they are within national societies.

The power of the international arena to checkmate the plans of developmental states in the Global South tempers optimistic projections of the ability of democratic politics to move states toward distributive and welfare oriented goals, especially when the international arena is seen not just as a regime shaped by international organizations but rather as a hybrid structure in which the agendas of private global capital and individual nation states trying to maximize geopolitical advantage often dominate those of international organizations.

In the neoliberal era, international organizations must operate in the shadow of global capital. They have been seen as allies of private capital or as the agents of global capital. These characterizations underestimate their "relatively autonomous" role in shaping the overall in the international arena, but even so their behavior cannot be understood independently of the agendas of private capital. International organizations do dominate the direct production of norms and global rules (as Babb and Chorev explain), but private global strategies and agendas consistently shape and reshape the global arena, with powerful consequences for developing countries.

International organizations like the IMF and the World Bank, along with northern donor countries, continue to be the primary source of external capital for the poorest countries, but being attractive destinations for private capital is the sine qua non of financial equilibrium for middle-income nations. This became more obviously true as the 20th century drew to a close. Indeed, by the 1980 s, it appeared that the IMF was more important as a source of legitimation ("seal of approval") and an organizer of collective action among private global lenders than as a source of capital per se.

The 1997-98 East Asian financial crisis brought into sharp focus both the centrality of private global capital and its inability to manage its own collective action problems. The dynamic progress of several Southeast Asian countries and even Korea was rapidly undercut by massive capital outflows as the herd behavior that had led to over-lending was replaced by herd-like outflows. In recent months it has become clear that even China, the one country in the Global South that seemed immune to the tides of global capital outflow, was not invulnerable. Perhaps even more fundamental for the strategies of the state in the Global South, however, are the constraints imposed by anticipation of the reaction of "the markets" (i.e., the major global banks and other financial 
institutions). Policies that might appear to be anti-capital, whether local or foreign, are likely to be eliminated by the self-censorship of policy-makers and politicians even before becoming the focus of political debates. Once the power of capital is added to the global political equation, the limits on the policy space that nation states can feasibly explore become clearer and narrower. Adding private global capital to the equation does not eliminate consequential variations in social policy at the national level or the importance of democratic accountability, but it reframes their context.

Just as perspectives on the economic role of the state have evolved over time, the frames used to interpret the impact of international factors on national strategies have changed. In SCID's early decades in the 1960s and 1970s, dependency theory was still in vogue, especially given SCID's regional affinity with Latin America (see, for example, Chilcote 1976 or Remmer 1976). In recent years, however, globalization has become the theoretical rubric. Comparing the dependency perspective on the relation between national possibilities with the globalization perspective is instructive. In early dependency work (and even in work critical of dependency theory but influenced by it), the possibility of a more nationally controlled economy remained an ideal typical aspiration and political goal, even if one that was likely to be frustrated.

By the second decade of the 21 st century, the necessity of global integration was taken for granted. Compare, for example, two SCID articles published a quarter of a century apart: Becker's (1985) positive assessment of the possibilities for national development strategy even in a small country fully dependent on mineral resources, with the assertion in Whittaker et al. (2010) about the centrality of globally integrative strategies to developmental success, even for China - the country in the Global South with the greatest possibility for nationally-oriented development. While the hope of being able to combine this integration into the global political economy with national social and welfare goals had not been completely abandoned (e.g., Cardoso 2009), notions of economic autonomy have largely disappeared from even aspirational visions of development.

As the current century opened, then, theories of development were forced to assume that the power of global financial capital could not be escaped. The necessity of living in a world dominated by global capital was no longer debated. Whether this was an economic world that would be able to deliver wellbeing to the majority of the world's citizens was another question. Indeed, by the second decade of the 21 st century, the global political economy was viewed not only as crisis prone, but as incapable of dealing with the most fundamental global collective action problems, with climate change topping the list.

The failure of global markets to solve the day-to-day problems of local citizens and the resurgence of nationalist political strategies are mutually reinforcing. That is, the failure of global markets to deliver (especially when there is no economic means of escaping their effects) makes retrogressive nationalist politics more attractive, and the rise of nationalism makes solving global collective action problems more difficult. This is another way of thinking about the new vitality of illiberal democracy that is set out in Rodrik's article. It also provides another perspective on the loosely coupled international arena that Babb and Chorev expect.

The most interesting question is whether the increasing presence of China in the Global South creates a new set of opportunities. The answer depends first of all on 
whether China is capable of becoming a global hegemon or whether an unstable multipolar balance of power is a long-term prospect. Predicting what the effects of Chinese hegemony would be, were it to achieve some sort of hegemony, is even less obvious. Regardless of one's assessment of China's future role, states in the Global South face a high likelihood of confronting an unstable global regime, one incapable of delivering collective goods, driven by the uncertain vectors of geopolitical rivalries in which major powers share the agenda of global capital without being capable of preventing globally threatening collective action failures. In this context, we must return to questions of national political institutions.

Are there scenarios in which the interaction of democratic politics and a capable state can supersede the disadvantages of the current international arena? Are there plausible national political and economic strategies that can supersede negative externalities generated globally? Convincing answers to these questions are obviously beyond the capacity of even the best social scientists, but efforts to confront them are likely to become part of the agenda of SCID contributors in the next 25 years.

\section{Looking Ahead to SCID's 75th Anniversary: Speculations on the Future of Development Studies}

Reflecting on SCID's first half century provides a rich tapestry of questions and conundrums that are central to the evolution of development studies as a field. Imagining what a similar set of reflections might focus on at SCID's 75th anniversary is a precarious exercise, but also one that is provocative and worthwhile. In order to make the project less fantastical, we will limit it to a focus on the potential evolution of the arenas that we have already explored: democracy, inequality, the political economy of the state, and the evolution of the international arena.

Some likely continuities are obvious. The character and consequences of democracy will continue to be a preoccupation for development studies. One important future agenda is clear from the articles on democracy in this issue. The pessimistic logic of the expansion of illiberal democracy that Rodrik outlines stands in fundamental tension with the emergence of new forms of participation and institutional access underlined by Roberts. These contradictory trends have both grown up under the umbrella of formal, representative democratic institutions, but will have contrary effects on the future consequences of those institutions. Figuring out what factors explain the relative predominance of these countervailing trends in specific national contexts will provide a central challenge for analysts of democracy and development.

The persistence of a preoccupation with inequality can also be taken for granted. The multiple possibilities for new and interesting work hardly need underlining. Among the various dimensions of what Stewart has called horizontal inequality, gender has been an obvious lacuna in SCID's repertoire. Gender and development is a field that antedates SCID, yet throughout the period it was represented by only a couple of articles per decade. It is hard to imagine that this gap will not be filled in the decades to come. Indeed, a special issue on gender and development is currently under consideration.

Of the plethora of other avenues that debates on inequality might take, a few are worth noting. The Piketty treatise (2014) on inequality, with its focus on Europe, creates an obvious opportunity for development scholars interested in inequality. 
Specifically, there is the challenge to explain the fact (noted by Stewart) that declines in inequality in Latin America were about a half-century out of sync with the declines that are the centerpiece of Piketty's findings for Europe. An even more tempting puzzle is Stewart's central inequality paradox about the contradiction between actual policy making and what is accepted as desirable. If we assume the ideological hegemony of neoliberalism, then the central inequality paradox should not exist. Insofar as inequality can be interpreted as the result of market forces and incentives, there is no reason why it should not be accepted as desirable. Stewart's central inequality paradox would seem, then, to represent a departure from a consistent neoliberal position whose origins and implications are in need of explanation.

Preoccupation with the role of the state is also likely to persist, if not expand. The 1990s agenda promoting greater openness to global capital and greater sway for market logics domestically seems unlikely to make a comeback. Efforts to probe the underpinnings of the developmental state are likely to continue, but the constraints imposed on would-be active states by the international arena, particularly by global capital, set limits on the possibilities for success.

There is also another feature of state behavior that may well become an increasing focus of attention. The maximization of territorial power as a goal in itself and as a means of unifying popular support for the holders of state power was, in the early post World War II period, a central conceptual frame in development studies. It was not, however, a focus of attention for most of SCID's history. ${ }^{11}$ This seems likely to change. Nationalism is an obvious response to the increasingly problematic intersection of national development and the international arena. The weakness of neoliberal globalization as an organizing ideology and a vehicle for delivering economic benefits increases the attractiveness of nationalism as a political strategy, everywhere from China and the United States to South Africa and Sudan. The rise of illiberal democracy also fits with an increasing predominance of nationalist strategies. The original postwar frameworks for analyzing nationalism are unlikely to provide leverage for any resurgence of nationalism. ${ }^{12}$ Will SCID authors find new ways of understanding the interrelation of nationalism and development? This would be an important task.

China by the 2005-15 period was already the largest single country focus for SCID, superseding the Latin American countries that were SCID authors' traditional favorites and leading the shift toward increased interest in East Asia that began with the East Asian tigers and the developmental state. SCID's pages have reflected general interest in trying to figure out the dynamics of Chinese institutions, particularly at the state and local level, but also at the national level. Cracking the conundrum of why these institutions work (when they do work) and what kinds of political dynamics undermine their successful functioning (when they do not work) is clearly a project with a future.

Curiously, analysis of China's role in facilitating or hindering development in the Global South (or even the effect of the changing global context on China's own

\footnotetext{
${ }_{11}^{11}$ Hechter (2000) and vom Hau (2008) are among the interesting exceptions.

12 Consider, for example, Deutsch's (1953) classic.
} 
development) has not been a topic that SCID authors have explored. ${ }^{13}$ It is hard to believe that development studies can avoid tackling this topic over the next 25 years. China's global role is an obvious future addition to SCID's repertoire over the course of the next quarter century, but it is only one of several facets of the international arena that merit expanded attention.

SCID's analysis of the international arena has focused primarily on traditional economic and political actors - states, foreign investors, and international organizations. As Babb and Chorev underline, non-traditional actors like philanthropic foundations and public-private partnerships "have become omnipresent and highly influential." There is, however, another set of new global actors who may end up playing an even more important role in reshaping the international arena than the Gates or Clinton foundations and which are yet to be analyzed in the pages of SCID.

Ideologically driven networks willing to engage in unrestrained violence may have relatively little economic or political clout relative to powerful nation states or global corporations, but they are still changing the international terrain in profound ways. These "terrorist" networks do not easily lend themselves to conventional analytical frames, but their impact on development cannot be ignored and should not be underestimated. It would be surprising if analyses of the origins and consequences of these organizations did not begin to appear in SCID and other development journals over the course of the next quarter century. Up till now, of course, such articles have been mainly found in journals focusing on security issues.

At the same time, there is another set of international networks that are equally interesting, even if they are considered less newsworthy. The failure (whether due to incapacity or disinterest) of states and global capital to deliver crucial global public goods - such as policies to mitigate climate change - and the extent to which international constraints also limit the ability of nation states to deliver the same sorts of goods has created powerful incentives for social movements to develop their own international networks. Nowhere is this clearer than in the rich mélange of efforts to force nations and corporations to pay attention to the long term tragedy of climate change, but there are a variety of other efforts as well.

From the Brazilian landless workers movement (MST) to the International Domestic Workers Federation (IDWF) to the International Indigenous Peoples' Forum on Climate Change (IIPFCC), a multiplicity of groups are using international connections to enhance their bargaining power. Like terrorist networks and non-traditional actors highlighted by Babb and Chorev, transnational social movements reflect both the disappointing failure of traditional means of organizing the international arena and the frustrations of trying to get leverage operating only at the national level. They face long odds against being able to reorganize the international area in a way that improves global welfare, but they will almost certainly become a permanent feature of global development politics nonetheless. They epitomize a central challenge to SCID's next 25 years,

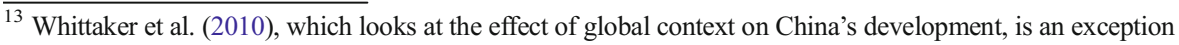
on this point.
} 
which is to explore the implications for development of an increasingly complex and contradictory international arena.

Acknowledgements Like SCID itself, the production of the 50th anniversary issue and of this article has been a collective endeavor. We would like to thank a number of people. The Watson Institute leadership, Rick Locke and Ed Steinfeld, provided the resources and support to make the 50th anniversary symposium possible. Christie Kilgus efficiently organized the logistics. Ben Bradlow, a sociology graduate student, worked with great skill and dedication to analyze the distribution of a half century of SCID articles and create the empirical foundation for our initial analysis. Sarah Babb, Nitsan Chorev, Ken Roberts, Dani Rodrik, and Frances Stewart gave generously of their time to write papers, attend the symposium, and help make the symposium a lively intellectual event. Commentators Peter Gourevitch and Patrick Heller added greatly to the quality of the discussion and of the revised versions of the papers. The SCID staff, MeganTurnbull and Marcelo Bohrt, helped in their usual efficient way. Finally, we would like to acknowledge the support of Ruth Berins Collier, former SCID editor, who helped us plan the symposium and special issue although she was unable to attend the event itself.

Open Access This article is distributed under the terms of the Creative Commons Attribution 4.0 International License (http://creativecommons.org/licenses/by/4.0/), which permits unrestricted use, distribution, and reproduction in any medium, provided you give appropriate credit to the original author(s) and the source, provide a link to the Creative Commons license, and indicate if changes were made.

\section{References}

Acemoglu D, Johnson S, Robinson JA. Institutions as a fundamental cause of long-run growth. In: Aghion P, Durlauf SN, editors. Handbook of economic growth, vol. 1A. Amsterdam: Elsevier; 2005. p. 385-472.

Amsden AH. Asia's next giant: South Korea and late industrialization. New York: Oxford University Press; 1989.

Baer M. Private water, public good: water privatization and state capacity in Chile. Stud Comp Int Dev. 2014;49(2):141-67.

Baiocchi G, Heller P, Silva MK. Bootstrapping democracy: transforming local governance and civil society in Brazil. Stanford: Stanford University Press; 2011.

Becker DG. Peru after the 'revolution': class, power, and ideology. Stud Comp Int Dev. 1985;20(3):3-30.

Berg AG, Ostry JD. Equality and efficiency: is there a trade-off between the two or do they go hand in hand? Finance and development (September). 2011;48(3):12-15.

Cardoso FH. New paths: globalization in historical perspective. Stud Comp Int Dev. 2009;44(4):296-317.

Cardoso FH, Faletto E. Dependency and development in Latin America. Berkeley: University of California Press; 1979.

Chilcote RH. Ruling classes and dependency in two backland communities of Northeast Brazil. Stud Comp Int Dev. 1976;11(2):35-50.

Deutsch K. Nationalism and social communication: an inquiry into the foundations of nationality. Cambridge: MIT Press; 1953.

Haggard S. Institutions and growth in East Asia. Stud Comp Int Dev. 2004;38(4):53-81.

Hechter M. Nationalism and rationality. Stud Comp Int Dev. 2000;35(1):3-19.

Huber E, Stephens JD. Democracy and the left: social policy and inequality in Latin America. Chicago: University of Chicago Press; 2012.

Johnson C. MITI and the Japanese miracle: the growth of industrial policy, 1925-1975. Stanford: Stanford University Press; 1982.

King L. Postcommunist divergence: a comparative analysis of the transition to capitalism in Poland and Russia. Stud Comp Int Dev. 2002;37(3):3-34.

Lakner C, Milanovic B. Global income distribution. From the fall of the Berlin wall to the great recession. Policy Research Working Paper 6719. Washington DC: World Bank; 2013.

Lindberg SI. Democracy and elections in Africa. Baltimore: Johns Hopkins University Press; 2006.

McGuire J. Political regime and social performance. Contemp Polit. 2013;19(1):55-75. 
Mukand S, Rodrik D. The political economy of liberal democracy. NBER Working Paper 21540. Cambridge, MA: National Bureau of Economic Research; 2015.

Negoita M, Block F. Networks and public policies in the global south: the Chilean case and the future of the developmental network state. Stud Comp Int Dev. 2012;47(1):1-22.

North D. Economic performance through time. Am Econ Rev. 1994;84(3):359-68.

O'Donnell G. Modernization and bureaucratic-authoritarianism: studies in South American politics. Berkeley: University of California Press; 1973.

Piketty T. Capital in the twenty-first century. Cambridge: Harvard University Press; 2014.

Portes A, Smith LD. Institutions and development in Latin America: a comparative analysis. Stud Comp Int Dev. 2008;43(2):101-28.

Przeworski A, Alvarez ME, Cheibub JA, Limongi F. Democracy and development: political institutions and well-being in the world, 1950-1990. New York: Cambridge University Press; 2000.

Remmer KL. Economic dependency and political conflict: Chile and Argentina, 1900-1925. Stud Comp Int Dev. 1976;11(2):3-24.

Roberts KM. Social inequalities without class cleavages in Latin America's neoliberal era. Stud Comp Int Dev. 2002;36(4):3-34.

Roberts KM, Wibbels E. The politics of economic crisis in Latin America. Stud Comp Int Dev. 2010;45(4): 383-409.

Rodrik D. Institutions for high-quality growth: what they are and how to acquire them. Stud Comp Int Dev. 2000;35(3):3-31.

Schmitter PC. Reflections on 'transitology' - before and after. In: Brinks D, Leiras M, Mainwaring S, editors. Reflections on uneven democracies: the legacy of Guillermo O'Donnell. Baltimore: Johns Hopkins University Press; 2014. p. 71-86.

Schurman RA. Chile's new entrepreneurs and the 'economic miracle': the invisible hand or a hand from the state? Stud Comp Int Dev. 1996;31(2):83-109.

Slater D. Democratic careening. World Polit. 2013;65(4):729-63.

vom Hau M. State infrastructural power and nationalism: comparative lessons from Mexico and Argentina. Stud Comp Int Dev. 2008;43:334-54.

Wade R. Governing the market: economic theory and the role of government in East Asian industrialization. Princeton: Princeton University Press; 1990.

Whittaker DH, Zhu T, Sturgeon T, Tsai MH, Okita T. Compressed development. Stud Comp Int Dev. 2010;45(4):439-67.

Wong J. Healthy democracies: welfare politics in Taiwan and South Korea. Ithaca: Cornell University Press; 2004.

Zakaria F. The rise of illiberal democracy. Foreign Aff. 1997;76(6):22-43.

Peter Evans is a Senior Fellow at the Watson Institute for International and Public Affairs at Brown University and Professor Emeritus of Sociology at UC-Berkeley. He is a member of the SCID Editorial Collective.

Barbara Stallings is William R. Rhodes Research Professor at the Watson Institute for International and Public Affairs and Editor-in-Chief of SCID. 